\title{
Protecting Environment, Managing E-Waste and Ensuring Development: Perspective on 'Waste Electrical and Electronic Equipment' Situation in Guiyu, Agbogbloshie and Dhaka
}

\author{
Muhammad Rehan Masoom ${ }^{1, a^{*}}$, Mohammad Mokammel Karim Toufique ${ }^{2, b}$ \\ ${ }^{1}$ Assistant Professor, School of Business \& Economics, United International University, \\ Bangladesh \\ ${ }^{2}$ Assistant Professor, School of Business \& Economics, United International University, \\ Bangladesh \\ arehan_1611@yahoo.com, ${ }^{b}$ mktoufique@gmail.com
}

Keywords: E-waste, Environmental Hazards, WEEE management, Guiyu, Agbogbloshie, Dhaka

\begin{abstract}
Fast development of the electronics industry and an eminent value of obsolescence of the electronic productions conduce to the uninterrupted production of great amounts of electronic waste or e-wasteworldwide. Due to the frequent commingling of a wide range of reusable, or recyclable, and non-recyclable surplus electronics, the term "e-waste" infer all sorts of these leftovers. Even though the economic benefits are potentially enormous, only a small proportion of the electronic waste is being recycled all around. There is a transaction cost associated with the recycling process due to the environmental protection regulations, hence economically less attractiveat the industry level in developed nations. However, to the least developed nations where owing to low living standard the demand for the better quality environment is low, even nonexistent, recycling e-waste has become a livelihood earning opportunity. The study intends to interpret the socio-economic consequences of e-wastes by focusing the detrimental effects that it have created in China and Ghana, and attempts to outline what developing nations like Bangladesh can do to prevent or reduce the harmful consequences of it.
\end{abstract}

\section{INTRODUCTION}

Economic growth, financial progress, technological advancement and societal change have become the common concern for all academic disciplines, so does the concern for the Environment. Developing or developed countries may fight with the trade issues, or South can blame the North for economic exploitations, but when the environmental degradation is concerned, the whole world tends to come under one umbrella. Probably, the number of summits or world conferences related to protecting and maintaining the ecological balance can out-numbered the rest of the gatherings as such. This growing concern is actually the eventuality of the negative effects of the ever-growing elements that can deplete the ecological balance. The environment is not just the matters or elements around us; it is much more than that. It is the aggregate of surrounding things, conditions and influences, such as the air, water, minerals, organisms, and all other external factors that have the capacity to affect the shape of life of a person or a population at any time [1]. It is not only nature but also the manmade social conditions that can be put together in one concept, 'Environment'. Hence, discussing the socio-economic factors are no less important that the concrete bio-chemical substances that can hamper the harmony of the ecosystem. An intellectual exchange and collaboration between environmental scientists and the social scientists are essential to interpret the present intricate situation. The present study deals one of the most critical factors of the present time and required an urgent attention, that is--'E-waste.'

The term 'e-waste' or 'waste electrical and electronic equipment (WEEE)' in general refers to "all components, subassemblies and consumables that are part of the electrical and electronic product at the time of discarding" [2]. These are primarily the materials or substances originated from the discarded computers or any other electronic equipment from the organizations that have 
upgraded their electronic tools. Then again, some entertainment devices like mobile phones, television sets, refrigerators or other home appliances that the owners like to get rid of from their homes are the other fundamental soucce of e-waste. The European Community directive 2002/96/EC on WEEE categories e-wastes in various distinct ways, such as (a) Large and Small Household Appliances, (b) IT and Telecommunications, Toys, Leisure, Sports and other consumer Equipment, (c) Electrical and Electronic Tool and Lighting Equipment, (d) Medical Devices and Automatic Dispensers, and (e) Monitoring and Control Instruments. A complex electronic device can have up to sixty different varieties of elements that can be reused [3]. Hence, e-waste offers an enormous opportunity for the developing nations to make certain a substantial level of growth. For example, Guiyu of China is the biggest dumping ground of e-wastes due to the higher competitive prices it pays in return, whereas the ICT-driven development agenda of Ghana makes Agbogbloshie an eminent trading place for e-wastes. The rapid increase in the usage of computer and the growing interests of using mobile phones or electronic gadgets in one hand, improper environment protective regulations and lack of awareness of the detrimental effects of e-waste among the people on the other, make Bangladesh a possible future Guiyu or Agbogbloshie [4]. The study intends to interpret the socio-economic consequences of e-wastes by focusing the detrimental effects it have created in China and Ghana, and attempts to outline what developing nations like Bangladesh can do to prevent or reduce the harmful consequences of it.

\section{DISCUSSIONS}

\subsection{The E-waste Paradox}

Today's society revolves around technology, and due to the constant need for the cutting-edge high-tech products, people tend to generate a massive amount of e-waste [5]. E-wastes are the electronic components that are destined for reuse, resale, salvage, recycling, or disposal [6]. The usage of e-wastes are either (a) forming something re-usable from working and repairable electronics, or (b) get the raw materials such as copper, steel, plastic or so on commonly termed as 'secondary scrap', which can be commoditized. These secondary scarps are the residue or materials that the buyers or consumers like to dump them rather than recycled or resale. Ever since the invention of LCD or LED televisions and monitors, the organizations begin to discard their old Cathode ray tubes (CRTs) devices in a wide scale as those equipments require large spaces. Unfortunately, these CRT devices are the hardest types to recycle [7]. From the time when the usage of Smartphones, or devices that use touch technology, cell phones became widespread among the people worldwide, these have become the topmost source of e-waste from the household. This is because most of these devices do not meant to be long lasting, sometimes even less than two years. Cell phone companies give their products such short life spans so that the consumer will long for the new ones and that in return ensure the margin of profit and growth of the business [8]. In the United States alone, of about seventy percent of heavy metals in landfills are from discarded electronic commodities [9]. However, developed countries like the USA can formulate and regulate policies with a certain level of ease, the developing countries like Bangladesh, where the electronic industry is about to flourish, faces a tremendous amount of challenges to manage e-waste.

E-waste is a resource as it can be reused and recycled before disposal [10]. Rare earth materials used in electronics are finite in nature. Therefore, we need sustainable and efficient usage policy for these resources. Between 2014 and 2018, the world's generation of e-waste is expected to rise from 41.8 million metric tons to 50 million metric tons [11]. The revenue from this market is forecasted to be $\$ 20.25$ billion in 2016, an $\$ 11$ billion increase from its 2011 level of $\$ 9.15$ billion. Recycling rates and procedures differ across countries and materials [11]. Listed below are some general benefits of recycling programs:

1. The recycling process requires a substantial workforce and creates new employment opportunities. 
2. The ecosystem is saved from a huge amount of hazardous toxins. However, it is difficult to gauge the cash-value of this impact.

3. Recycling saves the costs of shipment of e-waste (management and transportation) to the dumping grounds.

4. Many electronics manufacturers buy old products from recycling facilities. This reduces the cost of inputs and hence the price of the final product as well and adds to the consumer surplus.

5. Since the manufacturers can get the scarce resources from the recycling facilities, resource extraction decreases, helping resource conservation.

6. The recycling procedures consume less energy compared to the mining procedure.

7. The positive externalities also include conserving landfill space, diminishing greenhouse gas emissions.

8. Additionally, there are prospects for future business and research opportunities.

Even though the economic benefits are potentially enormous, only a small proportion of the electronic waste is being recycled. At the consumer level, there is a transaction cost associated with the recycling process, which makes it less attractive. This is kind of a trap - since not everyone is participating in recycling, the cost is high and since the cost is high, none is participating. One solution would be to enact a legislation defining the equilibrium or optimal level of pollution where all the stakeholders incorporate others strategies while devising strategies of their own. An alternative approach would be to impose a Pigouvian tax (= marginal social cost - marginal private cost) on the polluters [12]. However, issues like identification problem and intergenerational equity make its application difficult.

The nations of the world getting more connected day by day and this simply implies that the ewaste streams will keep on rising. In many developed countries, electronic waste is the fastest growing component of solid waste. Nevertheless, the recycling programs are not growing at a commensurate pace. That is because the profitability of such programs are greatly amputated by high labor costs combined with stringent environmental and safety measures. These are the very reasons for which products are sent to many developing countries. With the products, the negative externalities associated with e-waste are also transferred to the least developed nations where owing to low living standard (i.e. income) the demand for the better quality environment is low, even nonexistent. Providing a subsidy to the recycler in a developed country will not solve the problem, as the subsidy required to make recycling competitive would be quite large. Developing countries have lax labor and environmental laws and the labor is cheaper which give them an advantage over the developed world. However, even if they adopt stricter labor and environmental regulations, they can still manage to do the job at a lower cost because of the low opportunity cost of labor and as a result, the e-waste recycling sector in the less developed world can still thrive.

Recycling is more expensive than disposing of e-waste in a landfill [13]. Landfills are popular because their private property rights are not defined and if defined, they are unenforceable. In addition, there is a 'free rider' problem, as landfills are usually non-excludable and non-rival, i.e. public goods. This leads to a market failure known as the 'tragedy of the commons' - users don't invest in landfills and overexploit them. One way to internalize the environmental cost is to levy a tax on the users. An effective e-waste management demands the following: (a) Quantifying and characterizing e-waste stream, (b) Identifying major waste generations, (c) Assessing the risks involved, (d) Developing and implementing policies and technologies that foster sustainable development [14]. At the global level, two proposed solutions have been to institute worldwide collection point systems and enforcing extended producer responsibility. Implementation of the later should encourage the goals of improving product designs and higher reuse of products. In practice, different countries and cities have adopted a number of measures to tackle the problem of 
e-waste management. They include: (a) Tax per unit of garbage, (b) Deposit refund system, (c) Government mandates setting recycle content standards, (d) Landfill tax.

Disposed end-of-life electronic and electrical devices, as mentioned earlier as the fastest growing waste stream around the world, however, unlike other waste forms, its involves a composite amalgamate of dangerous, and extremely unhealthful kinds of stuff that are unfortunately had attractive economic values. These e-wastes are often cheap sources of valuable base metals such as copper, tin, and in few cases, gold, silver, and palladium. Hence, the economic opportunities of extracting these metallic elements create them some desirable trade goods. In developing nations, the informal sector with their rudimentary methods to disassemble these mental egress large landfills exhibit substantial hazard to the environment, and jeopardizes the health of local people. The Blacksmith Institute and Green Cross International have carried out a survey in 2013 across more than 3,000 sites in over 49 countries to identify e-waste management situation [15]. They have found that the Agbobloshie e-waste dumping yard in Ghana's capital, Accra, poses the most intoxicated menace to human life. Guiyu, in Guangdong Province, China, comprises to be the biggest e-waste site on earth. One previous study in 2009 on the residents of Guiyu city showed that children dwelling in this area have perilously overhead blood lead levels (BLL) [16]. In addition, there is accented metallic element contaminant on surface water and sediments that could induce kidney problems, weakened immune system, brain and liver damage and other numerous neurologic abnormal conditions.

\subsection{The Case of Guiyu, China}

Since 2010, China is the largest exporter of electronic devices and paradoxically it is the country that imports the most e-wastes from around. Guiyu, that once was a simple rice-growing village in northeast Guangdong province, has become the well-known destination for the electronic wastes. Near about six thousand businesses and more than hundred thousands of the people of the city are entirely depending upon the e-wastes to earn their living. Guiyu is now the biggest dumping ground primarily because on one side, it pays relatively higher prices for the wastes as such, and on the other the people, including the women and children have become highly skillful to liberate minerals like aluminum, steel, copper and gold [15]. However, a number of unsafe practices adopted, such as open burning and dumping of hazardous e-waste into the rivers and lakes to complete the processing of those electronic devices. Therefore, the water of those lakes and rivers has come undrinkable and an overwhelming presence of lead is found. The Children of that town, when measured, have an excessive rate of lead in their blood as well [16]. The hazardous techniques of dismantling the e-wastes in the open ground lease barium leachate and toxic phosphor into the air [17]. Hence, several respiratory diseases and skin problems are the common concern for the people of the town. Further, with the risk of violent implosion and exposition to cancer causing polycyclic, the environment of Guiyu has the mellowest degree of cancer-causing toxins. The Government of China has taken various initiatives like enforcing the 'national e-waste legislation' to prevent further impairments [18]. They have built formal recycling factories, officially ban the activities like open burning and acid treatment. In addition, the authorizes have launched formal effective steps such as "Home Appliance Old for New Rebate Programme" through which millions of home appliances would be collected and treated properly. Further, a joint collaboration between the Chinese search engine Baidu and the United Nations Development Program plan has been taken to create an application that help the users to sell old electronic devices that may otherwise become secondary scraps thrown in the landfills.

\subsection{The Case of Agbogbloshie, Ghana}

Agbogbloshie, a suburb near to the capital of Ghana, Accra that at one time a simple wetland is now a toxic e-waste dumping site. The Blacksmith Institute indicates the area as the most toxic place in the world in 2014 [15]. Ghana articulated a policy in 2003 on Information and 
Communications Technology (ICT) to accelerate the growth of the country. The ICT-driven development agenda conduced to an eminent level of trading for the most part secondhand Electrical and Electronic Equipment (EEE) influx into the city from the European and North American nations. The Environmental Protection Agency (EPA) of Ghana reports that near about one-third of these imported devices are either non-functional or are near end-of-life. Due to the economic opportunities to flourish a secondary raw material markets, an extensive informal industry has emerged that fundamentally involve in extracting the valuable metals from the e-waste. Near about half a million people of the country depend on this landfill in Agbogbloshie for their livelihood. Poor, migrants and children often scavenge the waste by simply breaking the glasses of the non-useable CRT monitors and burn the casings to retrieve the desirable metals. Once again, due to the lack of specific national regulations on e-waste recycling in Ghana, the dismantlers and the recyclers need to work in dismaying conditions [19]. The unsafe practices of open burning on the ground unleash an exuberant level of lead, tin copper and zinc to the soils that eventually reach to the nearby water bodies due to the heavy rainfall [20]. To tackle the problem as such the government of Ghana, along with some non-governmental organizations like Blacksmith Institute, Green Advocacy, and Pure Earth have rendered some wire-stripping machines to recyclers and dismantlers to ensure a safe way of extracting the metals. The Ministry of Environment is drafting an e-waste bill, which purports a levy that the importers and manufacturers of electronic devices need to pay for the costs of collecting, handling, retrieving and environmentally sound disposition and recycling of electronic waste [21].

\subsection{The Case of Dhaka, Bangladesh}

The stable growth rate of Bangladesh over the last five years, (as estimated by worldbank, the annual growth rate of GDP for last five years is 6.1 percent) infers a higher possibility of developing 'consumerism' in Bangladesh. The RMG (ready-made garments) sector has chiefly contributed to this development; nonetheless, the wheel of the economy is also moved by a large transaction due to the buying and selling of electronic goods. Hence, it can be expected that the rising income, infrastructural development and trouble-free regulations will encourage expanding the electronic assembly industry. Beginning of the 1990's, sophisticated electronic products such as computers, satellite TV signal receiving equipment, washing machines, motorcycles, mobile phone or cordless telephones and product as such have started to be assembled in Bangladesh. However, Bangladesh's integration into the 'free market agreement' that allows duty-free importation of electronic commodities opens up the possibilities of moving towards higher value sectors per se. In recent years, one of the fundamental steps were initiated, when an agreement was signed in June, 2015 between state-run Bangladesh Hi-Tech Park Authority (BHTPA) and Summit Technopolis Limited (a sister concern of local conglomerate Summit Group) that jointly ventured with Indiabased Infinity Infosys Parks Limited [22]. Where this particular over a couple of hundred million dollar investment may definitely boost the growth of technology business, there will be a large amount of obsolescence of the electronic products or in other words - e-wastes.

The immoderate environmental degradation and health risks reported at Guiyu and Agbogbloshie need to be considered as a pre-indication for a country like Bangladesh that experiencing a rapidly emerging economy with a focus on Information and communication technologies as the driving force for development. Hence, it has become an essential act to implement schematic recycling proficiencies with proper enact regulations on e-waste that can circumvent a future potential crisis. The Government of Bangladesh, through its Department of Environment, is presently acting upon to constitute a set of rules to deal e-wastes [23]. This is a significant initiative as because any formal procedures can create a certain level of awareness among the people of the country. So far, the operations and processes of e-waste management for Dhaka city is predominantly the responsibility of the informal sectors [24]. The central operations of this unorganized trade concentrate around the places like Dholaikhaal, Dholaipaar, Nimtoli, and Gulistan, on few occasions even in Mirpur and 
Elephant Road. The scrap collectors bring large bulks of e-waste collected from households and offices to the places mentioned above. These collectors are often the non-adults, and more often than not they manually, or sometimes with their bare hand dismantle the electronic devices with no precaution whatsoever. The constituent parts that cannot be processed further, is dumped in neighborhoods or on few occasions, stored in repair shops to fix electronic gimmicks or as such. The workers or collectors plainly apply various unsafe and insecure ways such as acid treatment or even open burning to dismantlement the metals to get the desired items [25]. These informal sector workers regularly handle e-waste and often remain completely unaware and very often ignorant of their own diminishing health due to the recapitulated exposure to unsafe substances.

A recent study on the Dhaka city residents, who belongs to higher and middle-income groups, showed that average citizens, who are the consumers of the electronic commodity, are not well informed about the negative consequences of e-waste [26]. The survey was carried out to realize the level of knowledge and awareness regarding the impact of e-waste on the ecology. It was found that more than half of them are not even aware with the term e-waste, let alone the threats it poses. People bought these products predominantly because these are often trendy and are within their reach with affordable price [26]. About the question of disposal, they indicate that the non-working electronic goods that are large, such as fridge or refrigerator, are often stored in their homes, or sometimes sold to e-waste collectors. If those electronic devices were small and useable, such as mobile telephone or radios that handed down to relatives, and if unusable, they dumped in trash bins. While inquired about what are the key factors they reckon most strongly prior to disposing of electronic devices, the overwhelming majority (almost 80 percent) indicates that whatever option is convenient, throwing to the bin or selling to the collectors [27]. The users go for any of these options without any cautious thinking about the environment. However, the study reveals some positive sides as well. When some facts about the ill-effects about e-waste are revealed to them, more than half of the respondents (sixty-six percent) expressed that they are ready to take added strain to safely dispose of these sorts of wastes disregarding of the price they can have in exchange of those products [27].

\subsection{The Possible Measures}

Considering the situations of Guiyu, Agbogbloshie and Dhaka, the measures to regulate the conditions, whether voluntary or mandatory, need to be explored and outlined. The Organization for Economic Cooperation and Development (OECD) offers a list of possible ways to deal with ewastes. One of the prominent ways to deal with WEEE is the 'Extended Producer Responsibility (EPR)'. OECD defines EPR as 'an environmental policy approach in which a producer's responsibility for a product is extended to the post consumer stage of the product's life cycle, including its final disposal" [28]. Another well-known policy to deal with situations as such is the 'Polluter Pays Principle (PPP)' implying that "polluters need to pay for all environmental resources used, leaving them the free option of emission abatement or resource use in return for payment of the charge" [29]. The National Electronic Product Stewardship Initiative (NEPSI) offers another model called 'Advanced Recycling Fee (ARF)' that is "a fee collected from consumers or producers for recycling of the products they purchase or sell" [30]. The policies in nations like Japan and South Korea employ the principles of Polluter Pays Principle (PPP) and Extender Producer Responsibility (EPR) and sometimes, fiscal space like Advanced Recycling Fee (ARF), to constitute a system of accountability amongst the relevant stakeholders in the electronics industry. All parties - whether manufacturers, recyclers, local and federal government or the consumers - bear ordained obligations to ascertain the appropriate disposal and recycling of unusable electronic devices.

The key of making any multi-stakeholder scheme functions in the right way lies on building proper awareness among all concerned actors. The governments of the concerned countries need to play a determinant function in implementing mass education programmes to build mass awareness. 
The governmental and Non-governmental organizations along with the help of the private sectors of countries like India and Sri Lanka have collaborated to create awareness and drive changes [30]. India's biggest e-waste management corporation- Attero, collaborated with International Finance Corporation (a World Bank entity) initiated several awareness programmes to ensure that landfills remain free from e-wastes. They initiate trainings for the scrap collectors and the others, who are related to this informal sector. With the aim of creating awareness among the people, countries like India begin to use various mass media like seminars, workshops, posters, leaflets and so forth on the harmful sides of e-wastes. This Awareness Programme on Environmental Hazards of Electronic Waste under Digital India Initiative is actually associated with India's Ministry of Communications and Information Technology. Central Environmental Authority (CEA) of Sri Lanka also declared an awareness campaign titled National E-waste Management Week since 2014 with the regulatory arm that intends to collect huge quantities of waste electrical and electronic devices within their every one-week duration campaign.

\section{CONCLUSION}

The environment is not mere a matter of political or social concern, it is a responsibility for the present generation to protect is for the future. However, the environmental degradation more often than not, is simply the flip side to the ever-expanding consumption of goods andrelentless technological advancement. Fast growth of the electronics industry leads to the incessant generation of a huge quantity of e-waste. These wastes comprise of injurious chemicals such as lead, barium, beryllium, cadmium, mercury, phosphorus and other plastic additives. In the absence of appropriate disposition or reprocessing facilities, these harmful and very often deadly materials can create major health and environmental problems. In the absence of government regulations and without any imperativeness created by informed workers and conscientious consumers, manufacturers of electronic commodities bear trivial or no incentive to contend their products at its end of life. Although, the state of affairs in Bangladesh may not be as dismal as that of Ghana or China, but acting upon to build consciousness amidst the distinct stakeholders would be an effectual measure towards the safety management of an imminent crisis as such.

\section{References}

[1] The Random House Dictionary of the English Language (1977) Second Edition, Edited by Jess Stein and Laurence Urdang. Random House Inc (T). USA.

[2] Directive, E. U. (2002). 96/EC of the European Parliament and of the Council of 27 January 2003 on waste electrical and electronic equipment (WEEE). Official Journal of the European Union L, 37, 24-38.

[3] Kang, H. Y., \& Schoenung, J. M. (2005). Electronic waste recycling: A review of US infrastructure and technology options. Resources, Conservation and Recycling, 45(4), 368-400.

[4] Ansari, N. L., Ashraf, M. M., Malik, B. T., \& Grunfeld, H. (2010, June). Green IT awareness and practices: Results from a field study on mobile phone related e-waste in Bangladesh. In Technology and Society (ISTAS), 2010 IEEE International Symposium on (pp. 375-383). IEEE.

[5] Luthar, B., \& Kropivnik, S. (2011). Class, Cultural Capital, and the Mobile Phone. Sociologický časopis/Czech Sociological Review, (06), 1091-1118.

[6] Kahhat, R., Kim, J., Xu, M., Allenby, B., Williams, E., \& Zhang, P. (2008). Exploring e-waste management systems in the United States. Resources, Conservation and Recycling, 52(7), 955964. 
[7] Jang, Y. C., \& Townsend, T. G. (2003). Leaching of lead from computer printed wire boards and cathode ray tubes by municipal solid waste landfill leachates. Environmental Science \& Technology, 37(20), 4778-4784.

[8] Electronics take back Coalition (2014). Facts and Figures on E-Waste and Recycling.Retrieved on December 10, 2015. URL: http://www.electronicstakeback.com/wpcontent/uploads/Facts_and_Figures_on_EWaste_and_Recycling.pdf

[8] Huo, X., Peng, L., Xu, X., Zheng, L., Qiu, B., Qi, Z., ... \& Piao, Z. (2007). Elevated blood lead levels of children in Guiyu, an electronic waste recycling town in China. Environmental Health Perspectives, 1113-1117.

[9] Kozlan, Melanie (2010-11-02). "What is 'E-Waste' \& How Can I Get Rid Of It?!". Four Green Steps.

[10] Smith, Christopher S. (2015). "The Economics of E-Waste and the Cost to the Environment" Natural Resources \& Environment, Volume 30, Number 2.

[11] Baldé, C. P., Wang, F., Kuehr, R., \& Huisman, J. (2015). The global e-waste monitor-2014. United Nations University, IAS-SCYCLE, Bonn, Germany.

[12] Barnett, A. H. (1980). The Pigouvian tax rule under monopoly. The American Economic Review, 1037-1041.

[13] Drayton, Heather L. (2007) "Economics of Electronic Waste Disposal Regulations," Hofstra Law Review: Vol. 36: Iss. 1, Article 7.

[14] UNEP (2007). "E-waste Volume II, E-waste Management Manual”. International Environmental Technology Center. United Nations Environmental Program.

[15] Bernhardt, A., \& Gysi, N. (2013). The world's worst 2013: The top ten toxic threats. Blacksmith Institute and Green Cross Switzerland.

[17] Wong, C. S., Duzgoren-Aydin, N. S., Aydin, A., \& Wong, M. H. (2007). Evidence of excessive releases of metals from primitive e-waste processing in Guiyu, China. Environmental Pollution, 148(1), 62-72.

[18] Nnorom, I. C., \& Osibanjo, O. (2008). Overview of electronic waste (e-waste) management practices and legislations, and their poor applications in the developing countries. Resources, conservation and recycling, 52(6), 843-858.

[19] Brigden, K., Labunska, I., Santillo, D., \& Johnston, P. (2008). Chemical contamination at ewaste recycling and disposal sites in Accra and Korforidua, Ghana.

[20] Caravanos, J., Clark, E., Fuller, R., \& Lambertson, C. (2011). Assessing worker and environmental chemical exposure risks at an e-waste recycling and disposal site in Accra, Ghana. Journal of health and pollution, 1(1), 16-25.

[21] Grant, R., \& Oteng-Ababio, M. (2012). Mapping the invisible and real" African" economy: urban e-waste circuitry. Urban Geography, 33(1), 1-21.

[22] Quadir, S. (2015) Bangladesh gets go-ahead for first technology business park. Dhaka: Reuters. Retrieved on 01. Januar 2016, URL: http://in.reuters.com/article/bangladeshhitechpark-idINKCN0P80SR20150628

[23] Alam, M., \& Bahauddin, K. M. (2015). Electronic Waste in Bangladesh: Evaluating the Situation, Legislation and Policy and Way Forward With Strategy and Approach. Present Environment and Sustainable Development, 9(1), 81-101. 
[24] Ahmed, F. R. S. (2011, July). E-waste management scenario in Bangladesh. In WEEE/E-waste management workshop on take-back system (pp. 13-15).

[25] Ahmed, S. U. (2011). Informal Sector E-waste Recycling Practices in Bangladesh. Research report series: 60010.[Ekushey Boi Mela, Bangladesh.

[26] Mahboob, N. S., \& Rahman, R. R. (2015, August 28). Electronic waste: Why should you care? The Daily Star. Retrieved December 20, 2015, from http://103.16.74.132/op-ed/why-shouldyou-care-133597

[27] Rahman, R. R., \& Mahboob, N. S. (2015, August 5). Electronic Waste: The Story of Bangladesh The Daily Star. Retrieved December 20, 2015, from http://www.thedailystar.net/oped/politics/electronic-waste-the-story-bangladesh-121792

[28] OECD. Publishing. (2001). Extended Producer Responsibility: A Guidance Manual for Governments. Organisation for Economic Co-operation and Development.

[29] Turner, R. K. (1994). Economic incentives and environmental policies: principles and practice (Vol. 1). Springer Science \& Business Media. Page No. 62.

[30] Ferguson, M. E., \& Souza, G. C. (Eds.). (2010). Closed-loop supply chains: new developments to improve the sustainability of business practices. CRC Press. Page. 26.

[31] Sthiannopkao, S., \& Wong, M. H. (2013). Handling e-waste in developed and developing countries: Initiatives, practices, and consequences. Science of the Total Environment, 463, 11471153. 